\title{
Familial Glucocorticoid Deficiency Type 1
}

National Cancer Institute

\section{Source}

National Cancer Institute. Familial Glucocorticoid Deficiency Type 1. NCI Thesaurus. Code C123727.

Familial glucocorticoid deficiency caused by mutation(s) in the MC2R gene encoding the adrenocorticotropin (ACTH) receptor, also known as the melanocortin-2 receptor. 